\title{
Nondestructive Raman investigation on wall paintings at Sala Vaccarini in Catania (Sicily)
}

\author{
Germana Barone $^{1}$ - Danilo Bersani ${ }^{2}$ - Alessia Coccato ${ }^{3}$ - Debbie Lauwers ${ }^{4}$. \\ Paolo Mazzoleni ${ }^{1} \cdot$ Simona Raneri $^{1} \cdot$ Peter Vandenabeele $^{3} \cdot$ Davide Manzini $^{5}$. \\ Giuseppe Agostino ${ }^{6} \cdot$ Nicola Francesco Neri $^{6}$
}

Received: 7 June 2016/Accepted: 12 August 2016/Published online: 20 August 2016

(C) Springer-Verlag Berlin Heidelberg 2016

\begin{abstract}
In this work, the results of a Raman campaign for studying seventeenth-century Sicilian frescoes, by using two portable Raman systems, equipped with different excitation sources (785 and $1064 \mathrm{~nm}$ ), are proposed. The measurements were performed with the aim to provide an in situ diagnostic analysis of the wall paintings (in terms of colorants and preparation layer) and to support the conservators in the framework of the ongoing restoration. The combined use of the two Raman spectrometers has given a complete overview on the artist palette and on the state of preservation of frescoes, also informing us about the technique employed by the painter. Natural pigments as hematite, vermillion, goethite, lead red, lead white and carbon-based black pigments have been identified. Additionally, the application of a transitional RomanesqueRenaissance frescoes method has been noticed by the systematic combined presence of calcite and gypsum in the substrate. Finally, the analyses have highlighted the
\end{abstract}

Germana Barone

gbarone@unict.it

1 Department of Biological, Geological and Environment Sciences, University of Catania, Corso Italia, 57, 95129 Catania, Italy

2 Physics and Earth Science Department, University of Parma, Parco Area delle Scienze, 7/a, 43124 Parma, Italy

3 Department of Archaeology, Ghent University, SintPietersnieuwstraat 35, 9000 Ghent, Belgium

4 Department of Analytical Chemistry, Ghent University, Krijgslaan 281, 9000 Ghent, Belgium

5 MadatecS.r.1., Via Montegrappa, 18, 20060 Pessano Con Bornago, Milano, Italy

6 Superintendence of Cultural Heritage of Catania, Via Luigi Sturzo, 62, 95100 Catania, Italy presence of degradation products, mainly related to alteration of lead-based pigments.

\section{Introduction}

After the well-known earthquake in 1693, the southeastern Sicilian towns experienced a lively architectonic and artistic season. The earthquake destroyed likely, partially or entirely, fifty urban centers and intensive reconstruction works started. In this framework, the Baroque architectural style flourished and the majority of the new built monuments exhibited standards of beauty devoted to emphasize volumes and voids. The new artistic rules were applied in the buildings from outside to inside: painters revoked from the entire island decorated the rebuilt private and public buildings, cathedrals, and churches with exquisite frescoes on the walls and on the vaults. The town of Catania was widely reconstructed, and new monumental buildings were also established in the urban center. Among the protagonists and the financiers of the restoration and construction works, the Benedictine Monasteries of San Nicolò stand out. They decided to take advantage of the earthquake to transfer their monastery to the urban center of Catania, where they built a huge Benedictine Monastery following the coeval artistic style. A large number of architects were invited to work at this project, and numerous painters were mobilized in order to marvelously adorn the buildings.

The Monastery is nowadays considered the second in the world for relevance and extension [1] and is included since 2002 in the UNESCO Heritage List. Due to its relevance, the Monastery has therefore to be preserved and conserved. The preservation of such structures is quite complex, due to the association of different materials and parts (i.e., masonry, substrate, wall paintings). Regarding 
wall paintings, numerous agents (external ones as well as strictly related to the standing buildings) can affect their integrity and only appropriate restoration works can assure the maintenance of these object of art without damaging risks. In this sense, the planning of preliminary diagnostic campaigns is always highly recommended; archaeometric analyses can in fact help conservators and restorers, and also provide art historians with precise information about techniques and materials employed by the artists.

Among the paintings decorating the buildings of the Benedictine Monastery, the seventeenth-century frescoes on the vaults of the Sala Vaccarini Library are really fascinating. Several attempts of restoration were performed during the nineteenth century, mainly carried out in invasive way and without the support of appropriate diagnostic activities. For these reasons, part of the scenes was evidently damaged and, in 2014, a new restoration work was started with the aim to bring the frescoes to a more coherent appearance. This was an excellent opportunity to examine the artworks in order to establish an in situ diagnostic analysis of the wall paintings (in terms of colorants and preparation layer) and to support the conservators in the framework of the ongoing restoration. Of course, in consideration of the preciosity of the paintings, the application of noninvasive and nondestructive methodologies was required; among them, Raman spectroscopy was recently assessed as particularly suitable tool for the diagnosis of art objects, especially for paintings, plasters and mortars [2-5]. The method allows in fact the quick, nondestructive and contactless characterization and identification of inorganic and organic materials, widely employed in art and archaeometry. Additionally, the development of mobile instruments designed for in situ archaeometrical research brought this analytical method back to the top, especially in the case of unmovable artworks.

Therefore, in this study, an approach based on portable Raman spectroscopic analysis has been applied on the frescoes decorating the Sala Vaccarini Library with the aim to characterize (a) the pigments used by the painter; (b) the artistic technique employed; (c) the possible presence of overpaint and (d) the state of preservation of frescoes, including eventual degradation products and/or alteration of pigments.

\section{Materials and methods}

\subsection{Studied frescoes}

The investigated frescoes are located on the vaults of the Sala Vaccarini, one of the exquisite Libraries part of the sixteenth-century monumental complex of Benedictine Monastery in Catania (Sicily, Italy).
The construction of the Library, which would host the rich manuscript collections harvested by the Monasteries over the time, was directed by the architect Giovanni Battista Vaccarini. Finished in 1773, the Library currently preserves its original structural arrangement and numerous volumes collected by the Monastery as well as precious manuscripts. Besides the book collections, the wall paintings on the vaults represent one of the most fascinating aspects of the Library. They were realized in seventeenth century by the Sicilian painter Giovanni Battista Piparo using the fresco technique (according to bibliographic sources) and exhibit medallions with symbolic representation of Virtues, Arts and Sciences.

Among the medallions, four scenes have been selected for Raman spectroscopic analysis (Fig. 1), being representative of the "artist's palette" and exhibiting several conservation issues as well as degraded areas.

\subsection{Raman equipments}

Two portable Raman instruments equipped with different wavelength excitation sources have been used for the investigations: a portable EZRAMAN-I-DUAL Raman spectrometer (TSI Inc., Irvine CA, USA) and an i-Raman ${ }^{\circledR}$ EX BWTek portable Raman instrument.

The EZRAMAN-I-DUAL Raman system is a portable dual laser instrument [6]. It is a fiber-optic-based spectrometer equipped with a near-infrared diode laser $(785 \mathrm{~nm})$ and a green $\mathrm{Nd}$ :YAG laser (532 nm) and a thermoelectrically cooled CCD detector. For this work, the 785-nm line has been used with a spectral range/spectral resolution of $100-2350 \mathrm{~cm}^{-1} / 7 \mathrm{~cm}^{-1}$. The optical fibers have interchangeable lenses (focal length of 3,7 or $15 \mathrm{~mm}$ ) and an adjustable power with maximum output of $400 \mathrm{~mW}$. The selected laser power for these analyses was adjusted at about $30 \mathrm{~mW}$. The spectrometer can use $230 \mathrm{~V}$ $\mathrm{AC}$ or an internal and external Li battery. A laptop, present in the case, is connected to the spectrometer. The i-Raman ${ }^{\circledR}$ EX is a portable BWTek Raman system equipped with a 1064-nm line. Using a high sensitivity thermoelectrically cooling InGaAs array detector with deep and high dynamic range, this portable Raman spectrometer delivers a high signal-to-noise ratio without inducing auto-fluorescence. The system provides spectral resolution as fine as $9.5 \mathrm{~cm}^{-1}$ and a spectral coverage range from 175 to $2500 \mathrm{~cm}^{-1}$. It uses a fiber-optic probe with an adjustable laser power up to $450 \mathrm{~mW}$. A laptop, present in the case, is connected to the spectrometer.

Both spectrometers have been calibrated before each experimental session. All spectra, of both instruments, were recorded with a measurement time of 2-10 accumulations of 3-60 s each. The Raman probes were held at a few millimeters of distance in front of the object, 

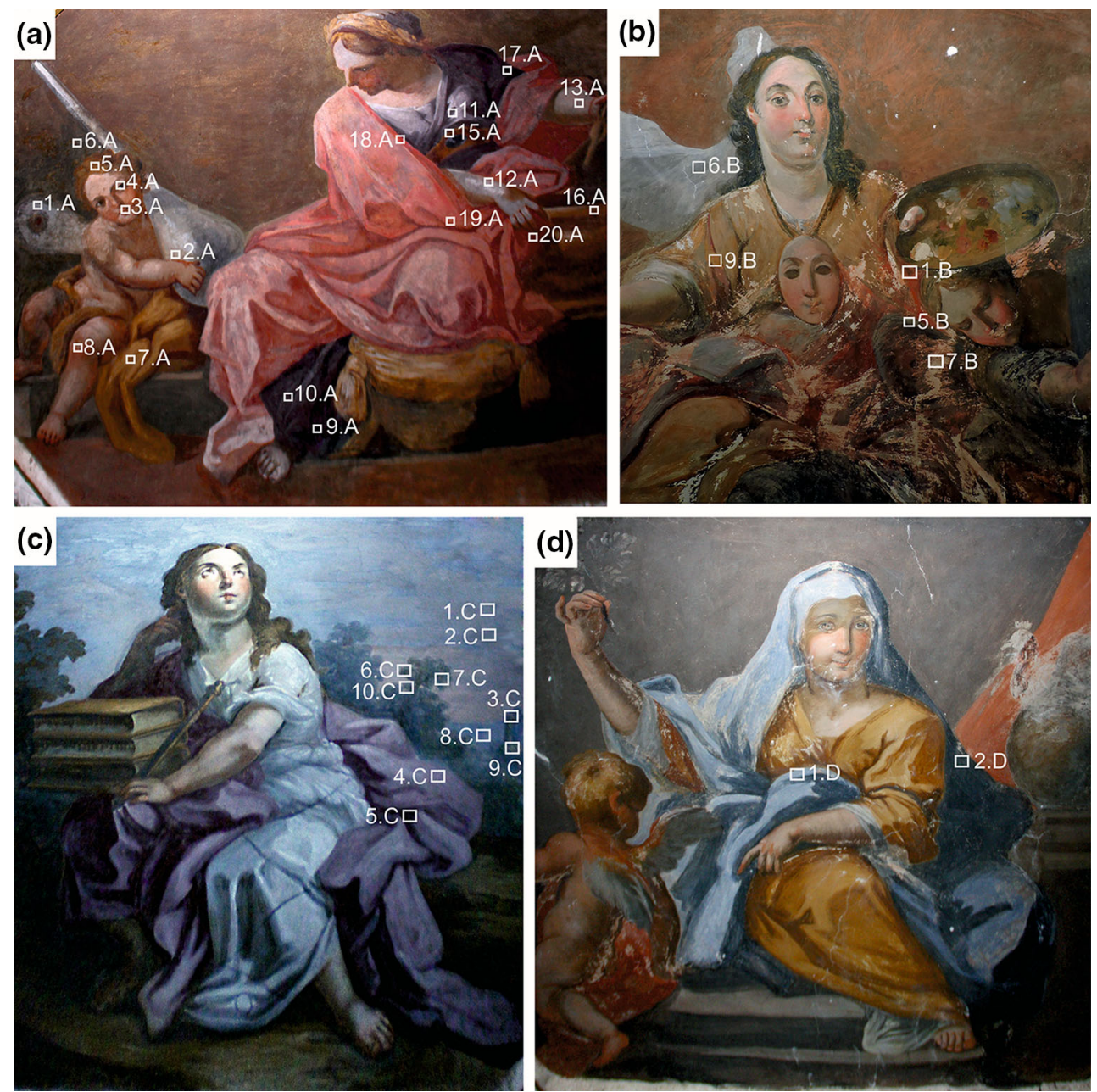

Fig. 1 Pictures of the studied medallions and measurement points. Symbolic representation of a "The Alchemy," b "The Art Painting," $\mathbf{c}$ "The Literature" and d "The Medicine"

corresponding to the focal distance of the lens. In the chosen configurations, the laser spot was c.a. $0.1 \mathrm{~mm}$ in diameter, allowing to obtain a real spatial resolution in the range of few millimeters. Due to the relatively large spot size, the laser power per area was too weak to induce any undesired effect or damage, even on organic or photosensitive materials, with both laser lines. The instrument output lens were shielded with a black cloth in order to minimize spectral interference from ambient light.

Referring to the data processing, the Raman spectra acquired by 1064-nm line have not been subjected to any data manipulation or processing techniques and are reported generally as collected, being characterized by very low fluorescence background. On the contrary, for spectra collected with $785 \mathrm{~nm}$, a baseline correction has been applied in order to better visualize the Raman signal. In general, during the measurement campaign, as both instruments were connected via a USB cable to a laptop, Raman spectra have been simultaneously visualized, allowing a real-time identification of materials. Of course, the final identification has been made by comparison with reference spectra present in the libraries of the authors and with the published literature.

\section{Results}

\subsection{Painted layers}

\subsubsection{Reddish hues}

Red-orange, pink and yellow hues were investigated in the medallions representing "The Alchemy" and "The Art Painting." In the Alchemy medallion, measurements were carried out by using both excitation sources, namely 785 nm (Fig. 2a-c) and 1064 nm (Fig. 2d). In detail, the pinkish color was measured on the skin of both women (points 12.A and 13.A) and angel (point 8.A). The obtained 

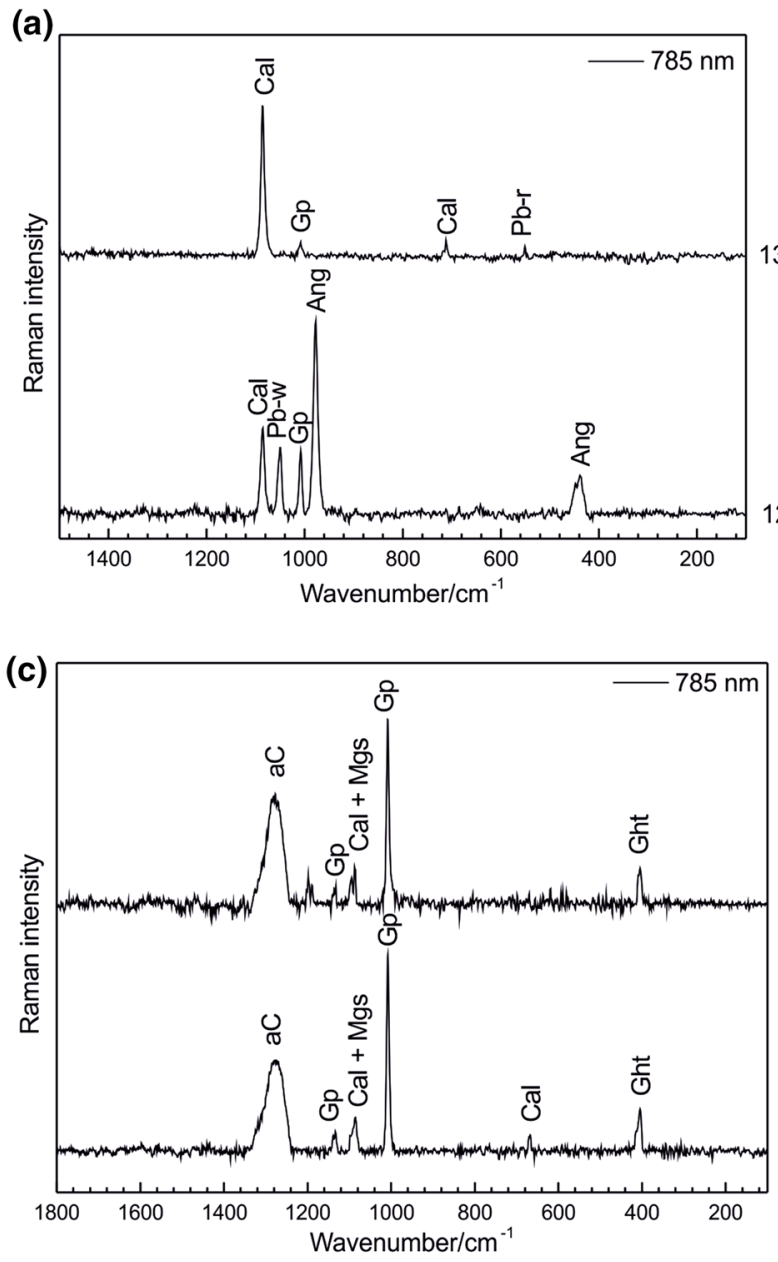

(e)

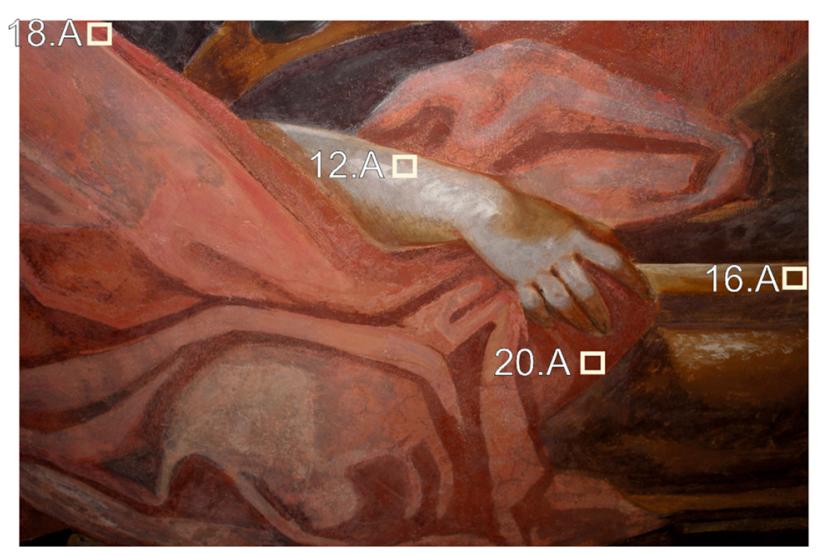

Fig. 2 Raman spectra collected in the medallion representing "The Alchemy" on a skin color, b red and $\mathbf{c}$ yellow layers by using $785-\mathrm{nm}$ line (baseline correction applied) and $\mathbf{d}$ skin color, red and yellow layers by using 1064-nm line; (e, f) detail of the investigated layers.

results suggest the use of a mixture of hematite $\left(\mathrm{Fe}_{2} \mathrm{O}_{3}\right.$; Raman bands at 620 and $412 \mathrm{~cm}^{-1}$ [7]) and lead white $\left(2 \mathrm{PbCO}_{3} \cdot \mathrm{Pb}(\mathrm{OH})_{2}\right.$; Raman band at $1052 \mathrm{~cm}^{-1}$ [8]). Additionally, the 785-nm laser detected the presence of red lead $\left(\mathrm{Pb}_{3} \mathrm{O}_{4}\right)$ (peak at $548 \mathrm{~cm}^{-1}$ ). Different tones of the
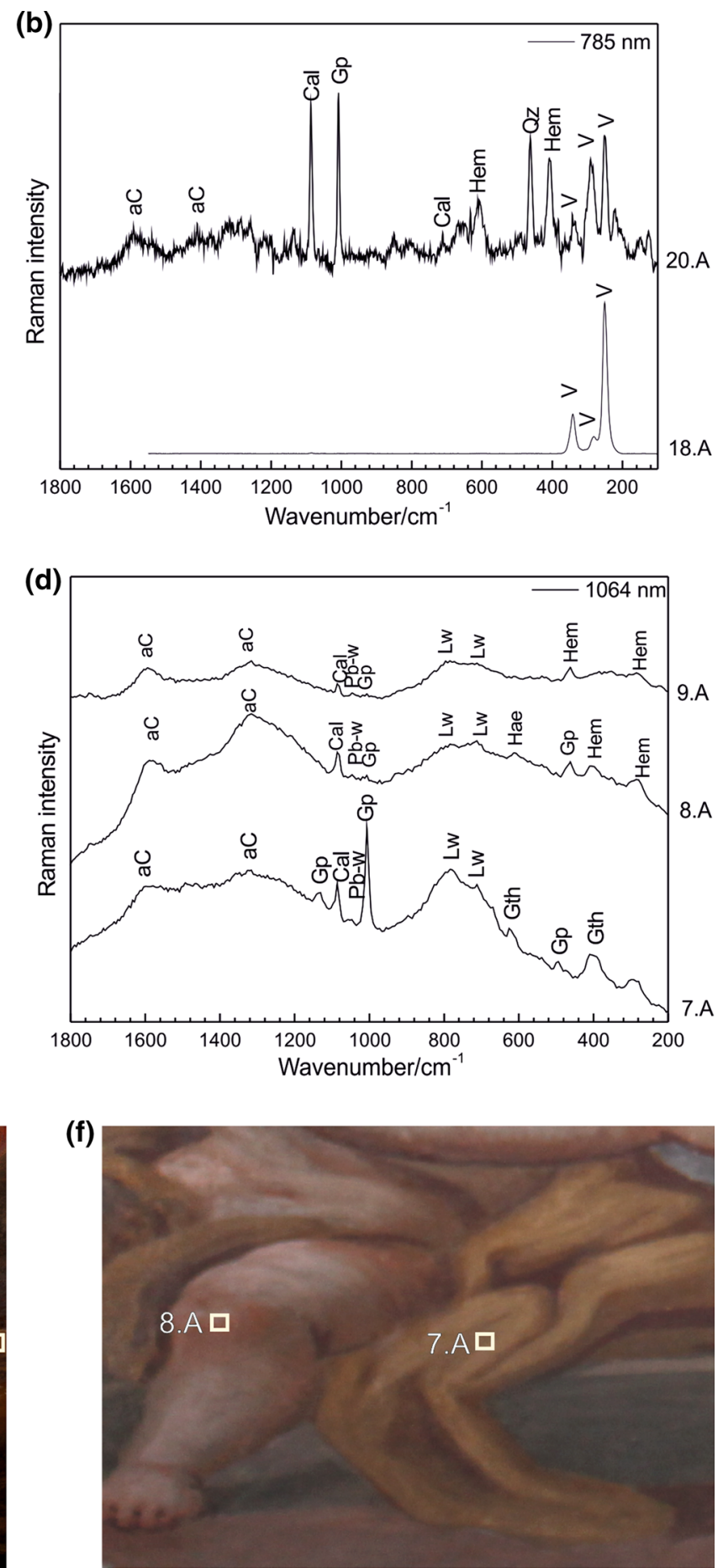

$a C$ amorphous carbon, Ang anglesite, $C a l$ calcite, Gth goethite; $G p$ gypsum, Hem hematite, $L w$ limewash, $M g s$ magnesite, $P b-r$ red lead, $P b-w$ lead white, $Q z$ quartz, $V$ vermillion

woman's vest were analyzed in order to characterize the pigmenting agents employed for obtaining the reddish hues. Measurements collected on bright red areas (point 18.A) reveal the use of pure vermillion $(\mathrm{HgS}$; typical Raman bands at 343,282 and $252 \mathrm{~cm}^{-1}$ [9]) that seems to 
be mixed with hematite (main peaks at 411 and $292 \mathrm{~cm}^{-1}$ ) and carbon-based black pigments (typical Raman features of amorphous carbon centered at 1588 and $1320 \mathrm{~cm}^{-1}$ [9]) for attaining bright shades of red (point 20.A). As far as the yellow hues present at the vase and the woman's belt (points 15.A and 16.A) and the angel's vest (point 7.A), the Raman spectra collected by using both excitation sources exhibit the typical peak of goethite $(\alpha-\mathrm{FeO}(\mathrm{OH})$; Raman band at about $403 \mathrm{~cm}^{-1}$ [10]). Finally, it needs to be noticed that the presence of $\mathrm{Pb}$ sulfates (anglesite, $\mathrm{PbSO}_{4}$ ) might point out the ongoing red lead alteration process due to atmospheric $\mathrm{SO}_{2}$ [11]. In fact, as evidenced by recent researches [12-14], such secondary phase is occasionally detected on discolored red lead [15], even if this soluble lead salt may be often leached during aging in humid conditions.

Going to "The Art Painting" medallion, measurements have been performed by using 1064-nm line on different red tones of the vest (points 9.B and 1.B) as well as on the angel skin (point 8.B). The analysis of the collected Raman spectra (Fig. 3) suggests, also in this case, the use of vermillion (HgS; Raman bands detected at 345, 280 and $252 \mathrm{~cm}^{-1}$ ) in the reddish-orange areas. Hematite seems to be used in order to obtain dark and light red hues, also mixed with carbon-based pigments (the presence of bands related to amorphous carbon). Finally, the use of a hematite and carbon mixture has been observed in the darker areas of the angel's skin.

\subsubsection{Grayish and black hues}

The interpretation of the collected Raman spectra on grayish and black layers reveals the prevalent use of

(a)

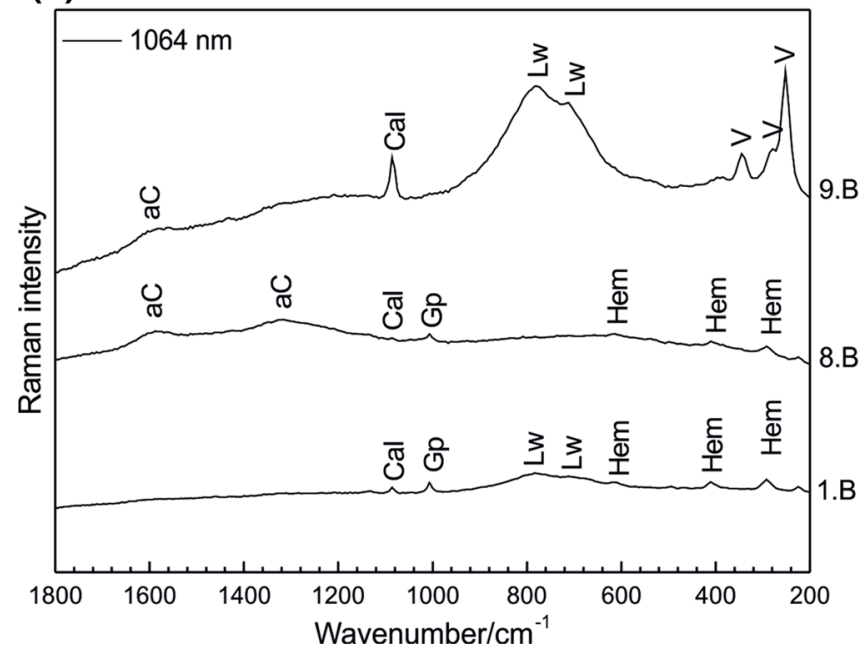

Fig. 3 Raman spectra collected in the medallion representing "The Art Painting" by using 1064-nm line on a skin color (point 8.B) and reddish layers (points 1.B and 9.B) and $\mathbf{b}$ a detail of the investigated amorphous carbon as pigmenting agent (Raman features centered at 1588 and $1350 \mathrm{~cm}^{-1}$ ), mixed with lead white (main Raman band detected at about $1052 \mathrm{~cm}^{-1}$ ). Such mixtures were detected at the measurements points established on the woman's vest (point 17.A), angel's wing (point 11.A) and ampoule (point 14.A) in the Alchemy medallion (Fig. 4a) and on the woman's voile (point 6.B) and angel's workbook (point 5.B) in the Art Painting one (Fig. 4b). Noteworthy is that the mixture of carbon-based black pigment and lead white seems to be employed also in order to obtain a grayish-purple hue in some parts of the women's vest represented in the Alchemy allegoric frescoes. In detail, the purple tone has been obtained by adding hematite to the mixture (see point 17.A in Fig. 4a). The presence of lead-based pigments suggests, also in this case, the occurrence of degradation products. In fact, thanks to the use of the 785-nm laser, anglesite $\left(\mathrm{PbSO}_{4}\right.$; Raman features at 978, 453 and $437 \mathrm{~cm}^{-1}$ ), have been detected in several grayish areas (see point 11.A in Fig. $4 \mathrm{a}$, as example).

\subsubsection{Green and blue hues}

In the medallions representing "The Literature" (Fig. 5a, b) and "The Medicine" (Fig. 5c, d), green and blue hues prevail. Globally, the analyses performed on different representative areas of the paintings did not allow the identification of the pigmenting agents responsible for these colors, as only Raman features attributable to lead white and carbon black were detected by using the 1064-nm line (Fig. 5a). The latter one maybe used in order to obtain darker tones. However, the employment of the 785-nm line has given again interesting results in

(b)

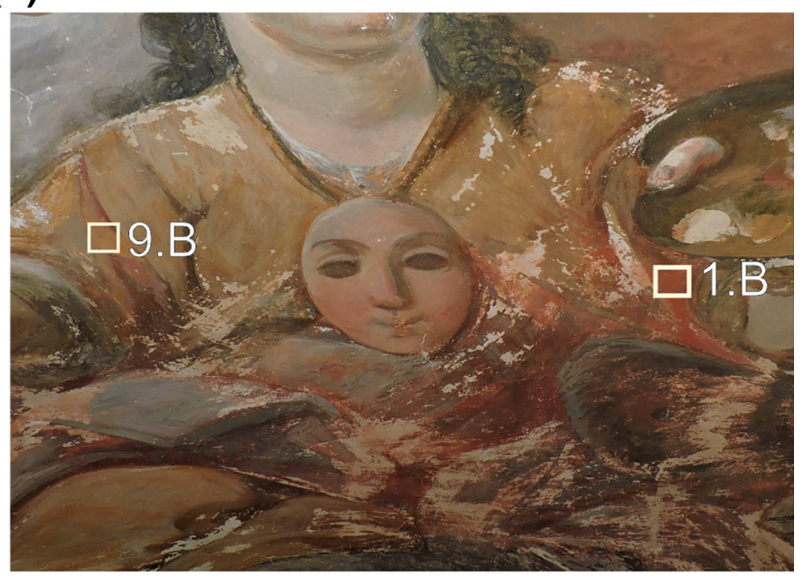

layers, as examples. $a C$ amorphous carbon, $C a l$ calcite, $G p$ gypsum, Hem hematite, $L w$ limewash, $V$ vermillion 
(a)

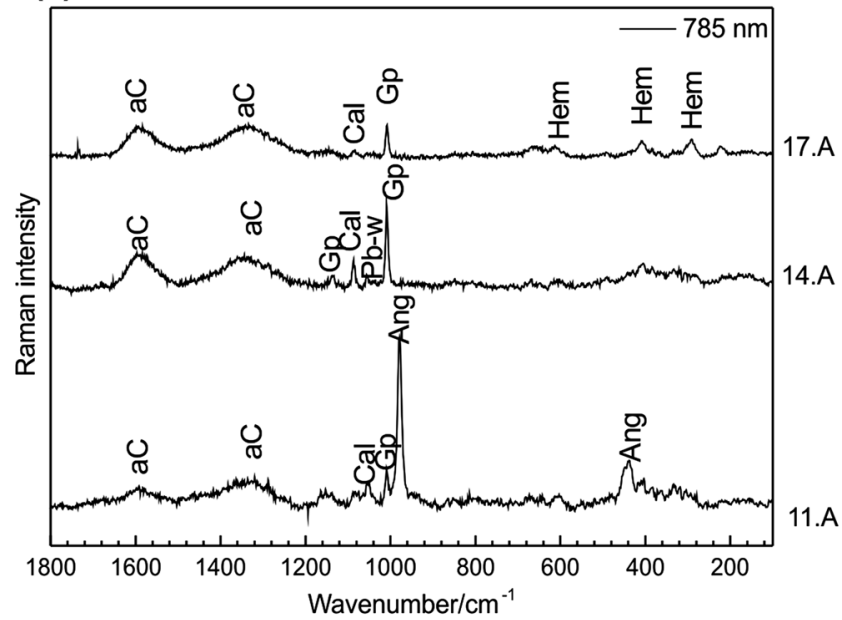

Fig. 4 Raman spectra collected on grayish layers: a measurement points (11.A, 14.A and 17.A) on "The Alchemy" medallion by using 785-nm line and b measurements points (5.B. and 6.B) on "The Art

comparison with the $1064 \mathrm{~nm}$ excitation source, supporting some hypotheses. In particular, spectra collected on green areas show the presence of weak Raman bands at about 125 and $846 \mathrm{~cm}^{-1}$ (Fig. 5b) that could be related to $\mathrm{Cu}-\mathrm{O}$ vibration or hydroxyl deformation in copper chloride minerals (such as atacamite and paratacamite; $\mathrm{Cu}_{2-}$ $\left.\mathrm{Cl}(\mathrm{OH})_{3}\right)$, frequently found in pigments of ancient paintings as result of malachite and azurite degradation [16, 17]. On the contrary, no pigments have been identified in the blue areas mainly investigated in "The Medicine" medallion. Notwithstanding, the detection of Raman bands attributed to the calcium oxalate whewellite $\left(\mathrm{CaC}_{2} \mathrm{O}_{4} \cdot \mathrm{H}_{2} \mathrm{O}\right.$; main Raman band at $1464 \mathrm{~cm}^{-1}$ ) could deny the use of copper salts as blue pigments (Fig. 5c). In fact, even if oxalates were largely detected as deterioration products due to lichens attach in works of art, especially in paintings, blue surfaces realized by using copper pigments are usually preserved as the $\mathrm{Cu}$ ions inhibit the growth of microorganisms [18]. Finally, worthy of note is the evidence of a recent restoration campaign (PB15 and anatase; see Fig. $5 \mathrm{~b}$ point 8.C) in the light blue background area of the Literature medallion scene.

\subsection{Substrate preparation}

Beside the Raman signals attributable to pigments, in all the spectra acquired by both excitation sources, a sequence of bands characteristic of calcite was detected (main Raman band at $1086 \mathrm{~cm}^{-1}$, usually associated with weak bands at 709 and $281 \mathrm{~cm}^{-1}$ ). This suggests a lime-based preparation layers and supports the bibliographic sources about the fresco technique used in the realization of the medallions. Indeed, the use of lime and its derivative for

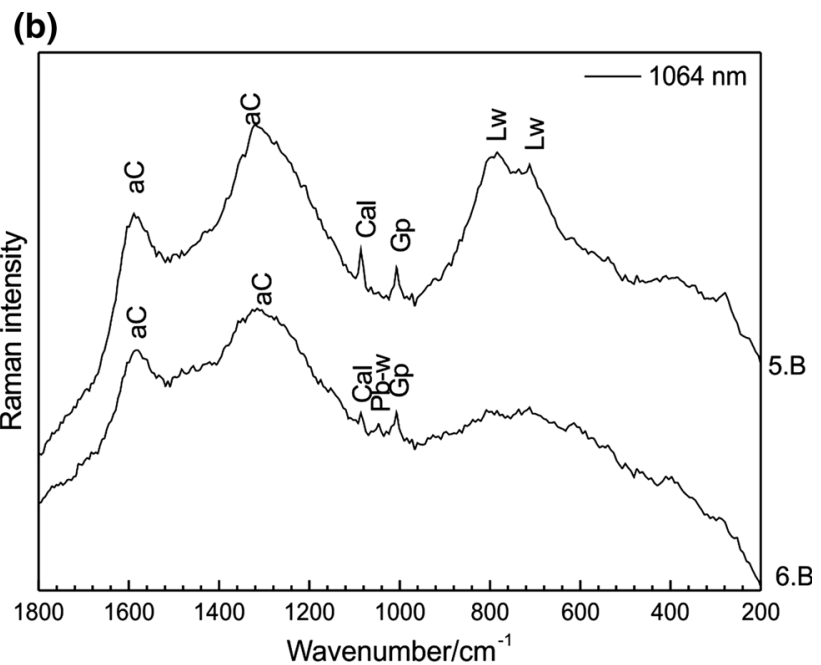

Painting" medallion by using $1064 \mathrm{~nm}$ line. $a C$ amorphous carbon, Ang anglesite, $\mathrm{Cal}$ calcite, $\mathrm{Gp}$ gypsum, Hem hematite, $\mathrm{Lw}$ limewash, $P b-w$ lead white

the preparation of surfaces to aid adhesion of pigments is widely attested over the time, especially from Roman to Renaissance period. Along with calcite, a band at $464 \mathrm{~cm}^{-1}$ reveals in some spectra the presence of quartz, informing us about the use of sand in the wall preparation (see Fig. 2b). As its occurrence varies significantly with sampling position, it could be an indication of variable composition of the mortar used in walls. Besides that, a more detailed inspection of the acquired spectra has provided additional information about the sourcing of materials, the methodologies of fresco preparation and the deterioration products.

The first interesting aspect is the concomitant presence of calcite and gypsum signals, characterized by the main Raman bands at about 1086 and $1008 \mathrm{~cm}^{-1}$, respectively (Fig. 6a). Usually, the presence of gypsum can be ascribed to the attack of sulfur dioxide from atmospheric pollution upon lime-based surfaces. However, in this case, because of the indoor exposure of the frescoes and the high intensity of both calcite and gypsum signals, it is possible to hypothesize the use of a transitional approach for the substrate preparation, widely attested in the literature, for which the two components are mixed together [19].

In addition, the presence of a broad feature in the form of a badly resolved doublet at about 790 and $710 \mathrm{~cm}^{-1}$ (Fig. 6b), in the spectra acquired with the 1064-nm line, is of great interest. Numerous researches, also performed on limewash/calcite wall paintings, have attributed this Raman feature to calcium hydroxides [20, 21], and it was not observed with lower wavelength excitation [22]. Even if may seem surprising, the conversion of limewash to calcium carbonate by reaction with atmospheric carbon dioxide is a relatively slow process and unconverted 
(a)

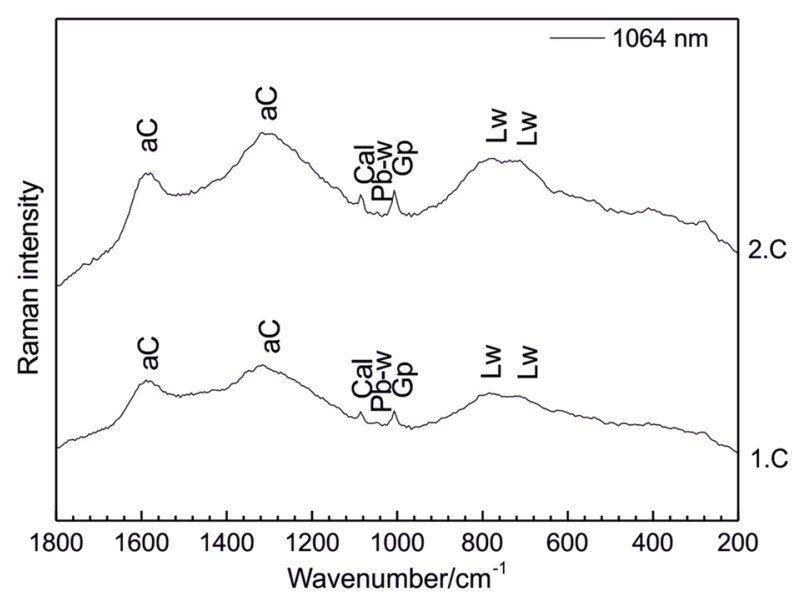

(c)

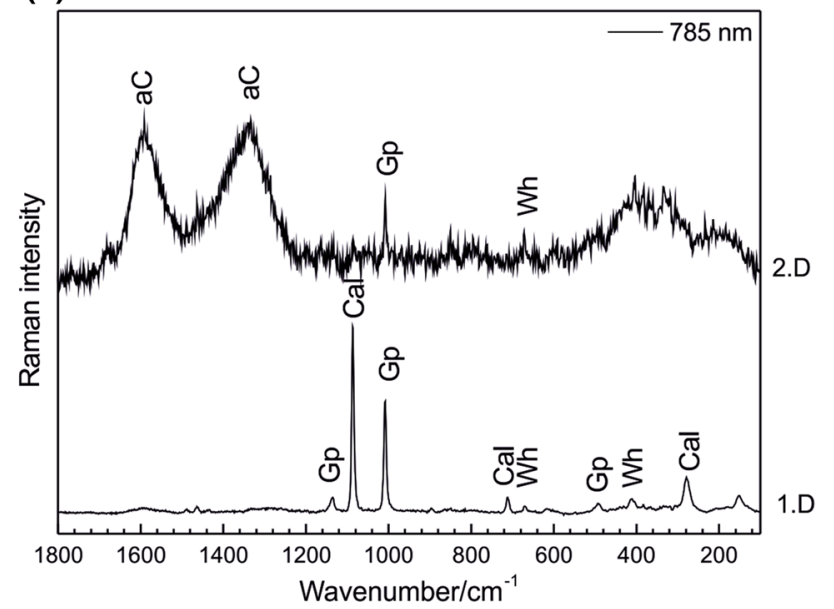

Fig. 5 Raman spectra collected in the medallion representing "The Literature" on greenish layers by using a 1064-nm line and b 785-nm line; c Raman spectra collected on "The Medicine" medallion on blue layers by using $785-\mathrm{nm}$ line; $\mathbf{d}$ detail of the investigated layers, as

(a)

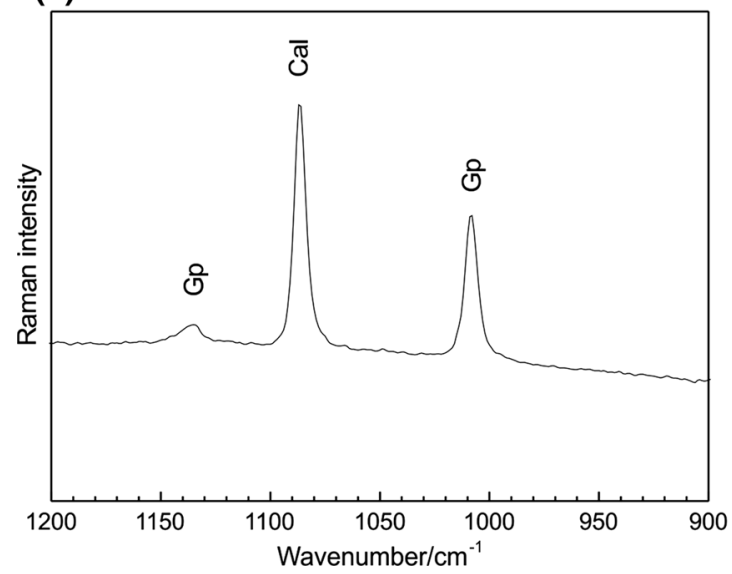

Fig. 6 Raman spectra collected on the studied frescoes representative of a the concomitant presence of calcite (Cal) and gypsum (Gp) suggesting the application of a transitional frescoes and $\mathbf{b}$ the (b)

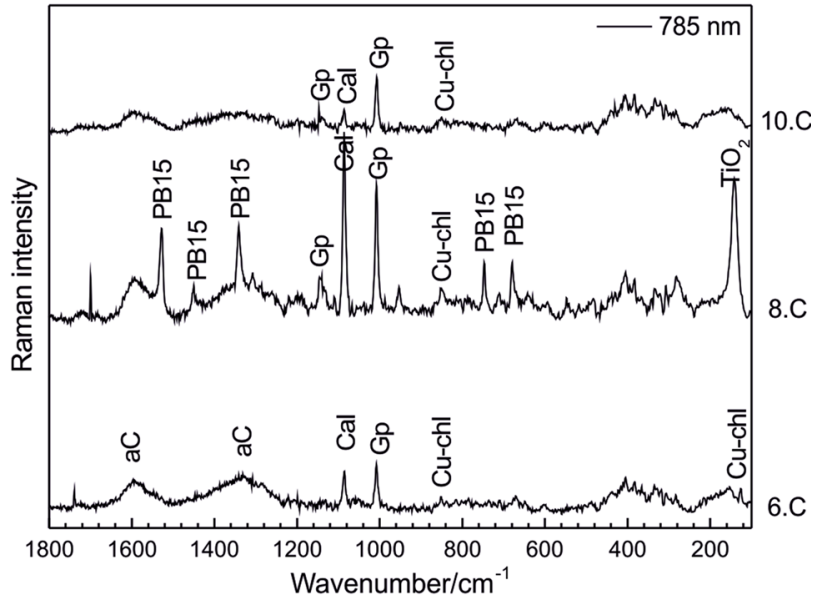

(d)

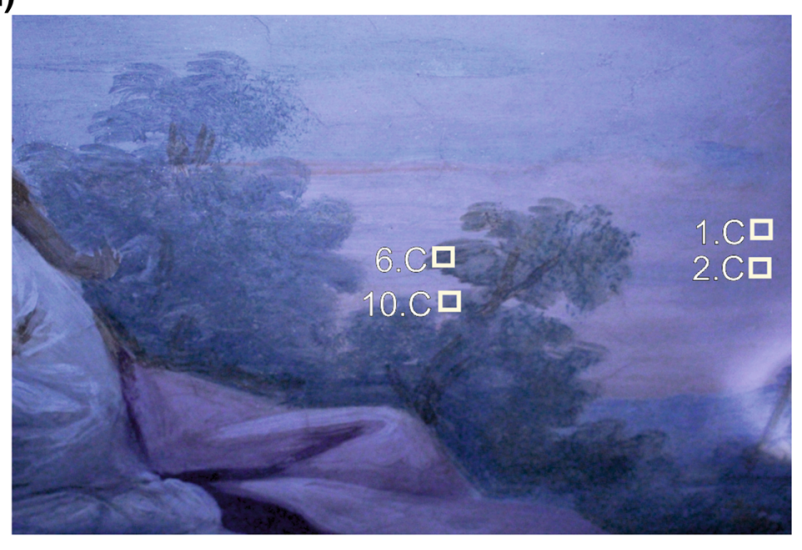

examples. $a \mathrm{C}$ amorphous carbon, $\mathrm{Cal}$ calcite, $\mathrm{Cu}$-chl copper chloride, $G p$ gypsum, $L w$ limewash, $\mathrm{Pb}-\mathrm{w}$ lead white, Verd verdigris, $\mathrm{TiO}_{2}$ anatase, $P B 15$ PB15, Wh whewellite

(b)

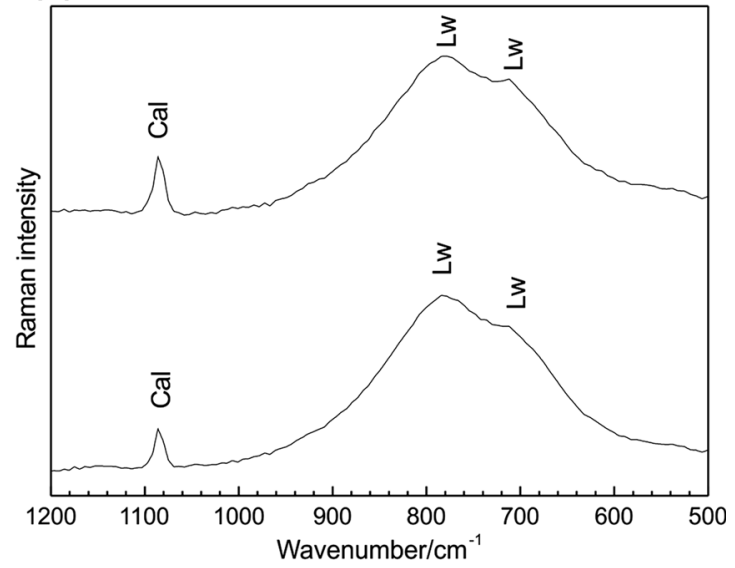

presence of calcite $\left(1086,713 \mathrm{~cm}^{-1}\right)$ with a greater relative proportion of unconverted limewash $(\mathrm{Lw})$, as testified by the broad features centered at about $780 \mathrm{~cm}^{-1}$ 
Table 1 For each medallion, measurement point IDs, color, main Raman bands (in $\mathrm{cm}^{-1}$ ) detected by using both wavelength (namely 785 and $1064 \mathrm{~nm}$ ) and attribution are reported

\begin{tabular}{|c|c|c|c|}
\hline $\begin{array}{l}\text { Analysis } \\
\text { point ID }\end{array}$ & Color & Raman bands $\left(\mathrm{cm}^{-1}\right)$ & Attribution \\
\hline \multicolumn{4}{|c|}{ Medallion A: symbolic representation of "The Alchemy" } \\
\hline \multicolumn{4}{|l|}{$1064 \mathrm{~nm}$} \\
\hline 1.A & Light gray & $1590,1320,1086,1007,790,710,280$ & Amorphous carbon, calcite, limewash, gypsum \\
\hline 2.A & Gray & $1590,1320,1086,1047,1007,790,713,280$ & $\begin{array}{l}\text { Amorphous carbon, calcite, limewash, lead white, } \\
\text { gypsum }\end{array}$ \\
\hline 3.A & Skin color & $\begin{array}{l}1590,1320,1086,1047,1007,790,713,620,490 \\
\quad 411,280\end{array}$ & $\begin{array}{l}\text { Amorphous carbon, calcite, limewash, lead white, } \\
\text { gypsum, hematite }\end{array}$ \\
\hline 4.A & Dark gray & $1590,1320,1086,1047,1007,790,280$ & $\begin{array}{l}\text { Amorphous carbon, lead white, calcite, limewash, } \\
\text { gypsum }\end{array}$ \\
\hline 5.A & Dark orange & $1590,1320,1086,1007,713,613,411$ & Amorphous carbon, calcite, gypsum, hematite \\
\hline 6.A & $\begin{array}{l}\text { Dark } \\
\text { background }\end{array}$ & 1590,1320 & Amorphous carbon \\
\hline 7.A & Yellow & $\begin{array}{l}1590,1320,1136,1086,1007,790,713,620,495, \\
\quad 404\end{array}$ & Amorphous carbon, calcite, limewash, gypsum, goethite \\
\hline 8.A & Skin color & $\begin{array}{l}\text { 1590, 1320, 1136, 1086, 1047, 1007, 620, 498, 411, } \\
292,226\end{array}$ & Amorphous carbon, calcite, lead white, gypsum, hematite \\
\hline 9.A & Grayish-purple & $1590,1320,1086,1047,1007,790,713,460,226$ & $\begin{array}{l}\text { Amorphous carbon, calcite, limewash, lead white, } \\
\text { gypsum, hematite }\end{array}$ \\
\hline 10.A & Grayish-purple & $1590,1320,1007$ & Amorphous carbon, gypsum \\
\hline \multicolumn{4}{|l|}{$785 \mathrm{~nm}$} \\
\hline 11.A & Gray & $1598,1056,1086,1050,1008,978,453,437$ & Anglesite, gypsum, lead white, calcite \\
\hline 12.A & Skin color & $1084,1054,1049,1008,978,447,437,280$ & Anglesite, gypsum, calcite, lead white \\
\hline 13.A & Skin color & $1086,1008,710,673,549,411,280$ & Calcite, gypsum, red lead \\
\hline 14.A & Gray & $1590,1134,1086,1054,1008,668$ & Amorphous carbon, lead white, calcite, gypsum \\
\hline 15.A & Yellow & $1269,1136,1086,1008,668,404$ & Goethite, magnesite, calcite, gypsum \\
\hline 16.A & Yellow & $1274,1197,1136,1096,1086,1008,403$ & Goethite, magnesite, calcite, gypsum \\
\hline 17.A & Dark gray & $1590,1330,1008,610,411,293$ & Amorphous carbon, gypsum, hematite \\
\hline 18.A & Bright red & $1086,340,281,251$ & Vermillion, calcite \\
\hline 19.A & Light red & $\begin{array}{l}1086,1009,712,604,463,404,383,343,336,289, \\
283,250,151\end{array}$ & Vermillion, hematite, calcite, gypsum, quartz \\
\hline 20.A & Dark red & $\begin{array}{l}1590,1134,1084,1006,848,633,604,462,406, \\
342,290,250,221\end{array}$ & $\begin{array}{l}\text { Amorphous carbon, vermillion, hematite, calcite, gypsum, } \\
\text { quartz }\end{array}$ \\
\hline
\end{tabular}

Medallion B: symbolic representation of "The Art Painting"

$1064 \mathrm{~nm}$

$\begin{array}{lll}\text { 1.B } & \text { Light red } & 1136,1086,1007,790,713,615,496,411,292 \\ \text { 2.B } & \text { Red } & 1136,1086,1007,790,713,615,495,411,292,225 \\ \text { 3.B } & \text { Light red } & 1086,1007,790,713,411,280 \\ \text { 4.B } & \text { Dark gray } & 1590,1320 \\ \text { 5.B } & \text { Gray } & 1590,1320,1086,1047,1007 \\ \text { 6.B } & \text { Gray } & 1590,1320,1086,1007,790,713,280 \\ \text { 7.B } & \text { Absence of } & 1086,790,710,280 \\ & \text { pigment layer } & \\ \text { 8.B } & \text { Skin color } & 1590,1320,1086,1007,615,411,292,225 \\ \text { 9.B } & \text { Reddish-orange } & 1086,790,713,345,280,252 \\ \text { 10.B } & \text { Black } & 1590,1320\end{array}$

Medallion C: symbolic representation of "The Literature"

$1064 \mathrm{~nm}$

1.C Light blue 1590, 1320, 1086, 1047, 1007, 790, 713, 280
Calcite, limewash, gypsum, hematite

Calcite, limewash, gypsum, hematite

Calcite, limewash, gypsum, hematite

Amorphous carbon

Amorphous carbon, lead white, calcite, gypsum

Amorphous carbon, calcite, limewash, gypsum

Calcite, limewash

Amorphous carbon, calcite, gypsum, hematite

Calcite, limewash, vermillion

Amorphous carbon

Amorphous carbon, lead white, calcite, limewash, gypsum 
Table 1 continued

\begin{tabular}{|c|c|c|c|}
\hline $\begin{array}{l}\text { Analysis } \\
\text { point ID }\end{array}$ & Color & Raman bands $\left(\mathrm{cm}^{-1}\right)$ & Attribution \\
\hline 2.C & Dark blue & $1590,1320,1086,1047,1007,790,713,280$ & $\begin{array}{l}\text { Amorphous carbon, lead white, calcite, limewash, } \\
\text { gypsum }\end{array}$ \\
\hline 3.C & Blue & $1590,1320,1086,1047,1007,790,713,280$ & $\begin{array}{l}\text { Amorphous carbon, lead white, calcite, limewash, } \\
\text { gypsum }\end{array}$ \\
\hline 4.C & Light purple & $1590,1086,790,713,411,280,225,157$ & Amorphous carbon, calcite, gypsum, hematite \\
\hline 5.C & Dark purple & $1136,1086,1007,615,493,411,292,225$ & Calcite, gypsum, hematite \\
\hline \multicolumn{4}{|l|}{$785 \mathrm{~nm}$} \\
\hline 6.C & Green & $1739,1590,1084,1006,851,129,125$ & Amorphous carbon, calcite, gypsum, copper chloride \\
\hline 7.C & Green & $1600,1086,1007,895,851$ & Amorphous carbon, calcite, gypsum, copper chloride \\
\hline 8.C & Light blue & $\begin{array}{l}1600,1528,1449,1340,1305,1285,1144,1130 \\
1108,1086,1008,987,951,850,746,709,679 \\
591,401,281,142\end{array}$ & $\begin{array}{l}\text { Amorphous carbon, calcite, gypsum, copper chloride, } \\
\text { anatase, PB15 }\end{array}$ \\
\hline 9.C & Light blue & $1600,1136,1086,895,711,670,490,411,279,154$ & Amorphous carbon, calcite, gypsum \\
\hline $10 . \mathrm{C}$ & Green & $1600,1140,1086,1006,950$ & Amorphous carbon, calcite, gypsum, copper chloride \\
\hline \multicolumn{4}{|c|}{ Medallion D: symbolic representation of "The Medicine" } \\
\hline \multicolumn{4}{|c|}{$785 \mathrm{~nm}$} \\
\hline 1.D & Light blue & $\begin{array}{l}1597,1487,1462,1432,1134,1084,1008,895,710 \\
\quad 669,503,491,410,278,150\end{array}$ & Amorphous carbon, calcite, gypsum, whewellite \\
\hline 2.D & Dark blue & $1600,1462,1320,1006,670$ & Amorphous carbon, gypsum, whewellite \\
\hline
\end{tabular}

calcium hydroxide can hang on for decades on wall painting substrates [19]. Based on this interpretation, we can suppose that, also in this case, the presence of the Raman bands attributable to slaked lime could be the evidence of a not complete conversion of lime to calcium carbonate.

Another interesting aspect, widely studied in ancient wall paintings studies, is related to the calcium carbonate source used for calcination; overall, the results obtained by the analysis of the collected spectra suggest the use of common limestone in the form of $\mathrm{CaCO}_{3}$. However, some spectra collected by using the 785-nm excitation line reveal a weak band at about $1092 \mathrm{~cm}^{-1}$ (see Fig. 2c) attributable to magnesite $\mathrm{MgCO}_{3}$ or dolomite $\mathrm{CaMg}\left(\mathrm{CO}_{3}\right)_{2}$ [23], pointing out the interesting hypothesis on the probable use of dolomitic limestone [24].

\section{Discussion and conclusions}

The overview of the Raman spectra collected on the studied frescoes (see Table 1) allows us to infer the following observations.

As far as coloring agents, red hues were mainly obtained by using vermillion, mixed with lead white and carbonbased black pigments in order to give back lighter and darker shades. However, the painter seemed to use also red lead and hematite, the latter one usually mixed with white pigments for the restitution of skin color. Referring to black and gray colors, they were realized by using carbonbased pigments and also mixed with white ones for making lighter tones. In the case of blue and green colors, no evidences of precise pigmenting agents have been collected, even if hypothesis on the use of copper salts for greenish hues could be proposed.

Referring to the preparation layer (in terms of composition, source materials and technique), the detection of bands related to calcium carbonate allows to assess the use of a lime-based preparation by employing the fresco technique. The systematic association of calcite with highintensity bands attributable to gypsum strongly supports the idea of the application of a transitional approach between Romanesque and Renaissance Art methods, in which both components were mixed together in the wall preparation. Moreover, the presence of Raman features related to $\mathrm{Si}-\mathrm{O}$ stretching modes $\left(464 \mathrm{~cm}^{-1}\right)$ suggests the use of sand in the mixture, even if not homogeneously distributed. The occurrence of magnesium-containing carbonates could provide information on possible marine carbonate sources. Finally, the presence of calcium oxide/hydroxide (band at $790 \mathrm{~cm}^{-1}$, only detectable with the $1064 \mathrm{~nm}$ laser), together with calcium carbonate $\left(1086 \mathrm{~cm}^{-1}\right)$, can provide information on the calcination degree. In this case, the relative intensity of these two bands suggests an incomplete process probably due to the indoor conditions.

The campaign offered also the possibility to compare the performances of the two employed portable Raman spectrometers that were used as well as the suitability of the 
different laser lines. In fact, the EZRAMAN-I-Dual Raman spectrometer has a wider spectral window (starting from $100 \mathrm{~cm}^{-1}$ ) in comparison with i-Raman ${ }^{\circledR} \mathrm{EX}$ (which ranges from 175 to $2500 \mathrm{~cm}^{-1}$ ), allowing the detection of compounds characterized by low-wavenumber Raman bands, such as lead-containing pigments, chloride minerals and $\mathrm{Pb}$ sulfate alteration products. At the same time, by working at $785 \mathrm{~nm}$, the identification of the minerals was made easier by the higher intensity of the Raman signal. On the other hand, as expected, lower fluorescence background has been observed by using the 1064-nm line, allowing the detection of compounds such as calcium oxide/hydroxide and carbon-based black pigments, characterized by broad Raman features. Apart from the aforementioned aspects, the use of the two instruments, equipped with a different excitation wavelength, produced very similar results in the majority of cases.

In conclusion, this study has allowed us to achieve a complete characterization of the pigments and technique used in the paintings of the vaults, supplying fundamental information to the restorers, useful for planning appropriate conservation and preservation actions.

Acknowledgments The authors are very grateful to the Superintendence of Cultural Heritage of Catania for having allowing and supporting the measurement campaign carried out in April 2014 during the restoration works at Sala Vaccarini in Catania. The authors thank Ghent University for its financial support through the concerted research actions (GOA) program.

\section{References}

1. V. Librando, in Quattro progetti per il Monastero di, ed. by S. Nicolò l'Arena, Università degli Studi Catania (Catania, 1988), pp. 11-27

2. A. Perardi, L. Appolonia, P. Mirti, Anal. Chim. Acta 480, 317 (2003)

3. P. Vandenabeele, J. Raman Spectrosc. 35, 607 (2004)
4. A. Deneckere, W. Schudel, M. Van Bos, H. Wouters, A. Bergmans, P. Vandenabeele, L. Moens, Spectrochim. Acta Part A Mol. Biomol. Spectrosc. 75, 511 (2010)

5. N. Buzgar, A. Buzatu, A. Apopei, V. Cotiugă, Vib. Spectrosc. 72, $142(2014)$

6. D. Lauwers, A.G. Hutado, V. Tanevska, L. Moens, D. Bersani, P. Vandenabeele, Spectrochim. Acta. A. Mol. Biomol. Spectrosc. 118, 294 (2013)

7. A. Zoppi, C. Lofrumento, E.M. Castellucci, P. Sciau, J. Raman Spectrosc. 39, 40 (2008)

8. A.M. Correia, M.J.V. Oliveira, R.J.H. Clark, M.I. Ribeiro, M.L. Duarte, Anal. Chem. 80, 1482 (2008)

9. L. Burgio, R.J. ClarkSpectrochim, Acta A Mol. Biomol. Spectrosc. 57, 1491 (2001)

10. S. Daniilia, D. Bikiaris, L. Burgio, P. Gavala, R.J.H. Clark, Y. Chryssoulakis, J. Raman Spectrosc. 33, 807 (2002)

11. M. Pérez-Alonso, K. Castro, I. Martinez-Arkarazo, M. Angulo, M.A. Olazabal, J.M. Madariaga, Anal. Bioanal. Chem. 379, 42 (2004)

12. S. Aze, J.M. Vallet, A. Baronnet, O. Grauby, Eur. J. Mineral. 18, 835 (2006)

13. S. Aze, J.M. Vallet, V. Detalle, O. Grauby, A. Baronnet, Phase Transit. 81, 145 (2008)

14. S. Daniilia, E. Minopoulou, Fr.D. Demosthenous, G. Karagiannis, J. Archaeol. Sci. 35, 1695 (2008)

15. E. Kotulanova, P. Bezdicka, D. Hradil, J. Hradilovà, S. Svarcova, T. Grygar, J. Cultural Herit 10, 367 (2009)

16. G. Bertolotti, D. Bersani, P.P. Lottici, M. Alesiani, T. Malcherek, J. Schlueter, Anal. Bioanal. Chem. 402, 1451 (2012)

17. R.L. Frost, W. Martens, J.T. Kloprogge, P.A. Williams, J. Raman Spectrosc. 33, 801 (2002)

18. R.L. Frost, M.L. Weier, J. Raman Spectrosc. 34, 776 (2003)

19. H.G.M. Edwards, D.W. Farwell, J. Raman Spectrosc. 39, 985 (2008)

20. D. Chiriu, P.C. Ricci, A. Polcaro, P. Braconi, D. Lanzi, D. Nadali, J. Spectrosc 14, 1 (2014)

21. H.G.M. Edwards, D.W. Farwell, D.L.A. de Faria, A.M.F. Monteiro, M.C. Afonso, P. De Blasis, S. Eggers, J. Raman Spectrosc. 32, 17 (2001)

22. A. Aminzadeh, Spectrochim. Acta, Part A 53, 693 (1997)

23. H.G.M. Edwards, S.E.J. Villar, J. Jehlicka, T. Munshi, Spectrochimica Acta Part A 61, 2273 (2005)

24. S. Bruni, F. Cariati, P. Fermo, A. Pozzi, L. Toniolo, Thermochim. Acta 321, 161 (1998) 